\title{
SERVICEBERRY CULTIVARS TESTED AS STREET TREES: INITIAL RESULTS
}

\section{by Henry D. Gerhold}

\begin{abstract}
Five serviceberry (Amelanchier) cultivars, 2 each in 11 communities, were planted for evaluation as street trees. They were measured annually for 3 years, and periodically afterwards, by cooperators in the Municipal Tree Restoration Program using standardized methods. 'Autumn Brilliance', 'Cumulus', 'Princess Diana', 'Robin Hill', and Tradition ${ }^{\circledR}$ all performed well in general, but they suffered somewhat from urban stresses. 'Autumn Brilliance' had healthier foliage, higher survival, and was broader but not as tall as the others.

Key Words. Serviceberry; Amelanchier; 'Autumn Brilliance'; 'Cumulus'; 'Princess Diana'; 'Robin Hill'; Tradition ${ }^{\circledR}$; street trees; performance testing.
\end{abstract}

Serviceberry (Amelanchier) cultivars are being evaluated as part of the Municipal Tree Restoration Program. MTRP encourages municipalities to improve their tree programs and provides information to help decision-makers select appropriate cultivars for planting under utility wires. Free trees purchased with utility funds serve as an incentive for communities to participate. Initial results of performance tests of crabapple (Malus) and Callery pear (Pyrus calleryana) cultivars were reported previously (Gerhold et al. 1994; Gerhold and McElroy 1994).

Earlier research comparing landscape trees (Reisch et al. 1971; Ticknor 1971; Mower 1973; Kozel 1974) led to the proposal of a cooperative performance testing system for street tree cultivars (Gerhold and Bartoe 1976; Gerhold 1985). The statistical design was based on measurements of 23 cultivars supplied by municipal arborists in Iowa, Michigan, Ohio, Pennsylvania, Vermont, and Washington (Bartoe 1977).

The taxonomy and nomenclature of Amelanchier species, and the assignment of various cultivars to particular taxa, are somewhat problematical. The cultivars 'Autumn Brilliance', 'Cumulus', 'Princess Diana', and 'Robin Hill' (as 'Robin Hill Pink') have all been considered as $A . \times$ grandiflora (Zabel) Rehd., natural hybrids between $A$. arborea (Mich x.f.) Fern and A. laevis Weig. The cultivar 'Trazam', registered as Tradition ${ }^{\circledR}$, has been assigned to $A$. canadensis (L.) Med. by its introducer.

\section{METHODS}

Ten communities in Pennsylvania and 1 in New York planted the serviceberry trees represented in this report. Community representatives chose the planting sites with assistance of utility foresters, service foresters, and Extension urban foresters; 2 of these usually assisted each community. A typical cultivar performance test consisted of 2 cultivars planted alternately within 4 to 10 plots that could contain 4 to 16 trees each, a total of 50 trees. All test trees were planted along streets and under electric conductors; the utility company arranged for removal of large trees that interfered with utility lines. Both cultivars for a community were ordered $B \& B$ from the same nursery, with calipers of 4.5 to $5.1 \mathrm{~cm}(1.75$ to 2 in.); heights ranged from 2.7 to $4.9 \mathrm{~m}$ (9 to $16 \mathrm{ft}$ ).

The cultivar tests were planted between 1989 and 1996. A trained cooperator inspected and measured the trees annually during the first 3 years, and then at 3-year intervals in most cases. During September or October, a service forester or Extension urban forester used s:andardized methods to measure tree height, trunk diameter, and crown width, and to classify foliage health, branch health, trunk health, maintenance needs, and overall quality (see scales in Table 1). Causes of damage such as disease, insects, drought, and mechanical injuries also were recorded.

An analysis of variance (MINITAB General Linear Model) was conducted on each type of quantitative data from the 2 cultivars in a community to calculate means and determine significance of differences. Each test location in every year was treated as a separate experirnent with plots providing replication. These results, along with written comments of cooperators, were used to characterize performance of the cultivars. 


\section{RESULTS}

All of the serviceberry cultivars performed well, at least at some locations, but they were more sensitive than other species such as crabapples and Callery pear (Gerhold et al. 1994; Gerhold and McElroy 1994) to urban stresses, caused for example by compacted soils, heavy traffic, and restricted spaces. Foliage health values below 3.5 (more than 20\% of foliage injured) indicated adverse site conditions particularly at Delaware Water Gap, Reading, and Union City (Table 1). Survival rates also suffered at some locations, but mainly for other reasons such as improper planting, vehicle accidents, and vandalism. Nearly half of the cultivar survival percentages within communities were below 80 .

Most of the serviceberry cultivars did not differ significantly and consistently from the others, with a single exception. 'Autumn Brilliance' in several comparisons was not as tall, had a broader crown, and had healthier foliage. The average percentage survival of 'Autumn Brilliance' at 6 locations, including 2 stressful ones, was $97 \%$, whereas the survival percentage of 'Cumulus', 'Robin Hill', and Tradition ${ }^{\circledR}$ averaged 79,76 , and 75 respectively.

Growth rates differed substantially among locations, and there were inconsistencies between cultivars. For example, 'Cumulus' grew faster than 'Robin Hill' at Bedford, but the reverse was true at Orrstown (Figure1). At Union City, the patterns of height growth of 'Autumn Brilliance' and Tradition ${ }^{\circledR}$ were similar, even though the latter was taller (Figure 2). However at Warren, Tradition grew little from year 3 to year 6 , whereas the height of 'Autumn Brilliance' increased more than $1.2 \mathrm{~m}(4 \mathrm{ft})$. The reasons for these growth differences are unknown.

There were few significant differences among branch health, trunk health, and maintenance needs (not shown). They were caused mainly by mechanical damage and transplant shock. Overall ratings also were variable, inconsistent, and generally differed by less than 1.0, except at Genesee where 'Autumn Brilliance' was consistently rated above 'Cumulus'.

\section{CONCLUSIONS}

All of the serviceberry cultivars performed reasonably well as street trees, but they were sensitive to the more stressful sites. Therefore, compacted soils, streets with heavy traffic, and restricted space for root development should be avoided. 'Autumn Brilliance', 'Cumulus', 'Robin Hill', and Tradition ${ }^{\circledR}$ all were tested for 6 to 8 years at 4 to 8 locations, indicating results can be used with confidence. 'Princess Diana' was planted only in 1 community but appears promising after 3 years. 'Autumn Brilliance' was broader, not as tall, had somewhat healthier foliage, and had higher survival after transplanting than the others. All had pleasing characteristics, along with single trunks and branching habits conducive to clearance for pedestrians and vehicles.

\section{LITERATURE CITED}

Bartoe, D.W., II. 1977. Statistical designs for evaluating and comparing street tree cultivars. M.S. thesis, Penn State Univ., University Park, PA. 98 pp.

Gerhold, H.D. 1985. Performance testing of street tree cultivars: A model project. J. Arboric. 11(9): 263-271.

Gerhold, H.D., and W.D. Bartoe II. 1976. Performance testing tree cultivars in metropolitan environments. J. Arboric. 2(12):221-227.

Gerhold, H.D., and H.L. McElroy. 1994. Callery pear cultivars tested as street trees: Initial results. J. Arboric. 20(5):259-261.

Gerhold, H.D., H.L. McElroy, and H.L.H. Rhodes. 1994. Street tree performance tests of crabapple cultivars: initial results. J. Arboric. 20(2):87-93.

Kozel, P.C. 1974. Shade trees for suburban and city arboriculture. HortScience 9(6):515-518.

Mower, R.G. 1973. Some observations on street tree plantings. Proc. Intl. Shade Tree Conf. 49:49-55.

Reisch, K.W., G. Hull, and H.M. Hill. 1971. Case histories of several street tree species and cultivars at selected sites in five Ohio cities. Ohio Agric. Res. Dev. Ctr., Hort. Dept. Series 376, 65 pp.

Ticknor, R.L. 1971. Landscape tree performance. Oregon State Univ., Agric. Exp. Sta., Circular of Information 633, $11 \mathrm{pp}$. 
Table 1. Growth, health, and combined ratings of serviceberry cultivars, derived from data collected for 3 or more years after planting. Average trunk diameter, tree height, and crown width are in the most advanced year; foliage health, branch health, and overall ratings are averaged over all years.

\begin{tabular}{|c|c|c|c|c|c|c|c|c|}
\hline Cultivar & Location & Year & $\begin{array}{l}\text { Diameter } \\
\mathrm{cm}\end{array}$ & $\begin{array}{l}\text { Height } \\
\mathrm{m}\end{array}$ & $\begin{array}{l}\text { Width } \\
\mathrm{m}\end{array}$ & $\begin{array}{l}\text { Foliage } \\
1-5^{z}\end{array}$ & $\begin{array}{l}\text { Branches } \\
1-5^{z}\end{array}$ & $\begin{array}{l}\text { Overall } \\
1-9^{y}\end{array}$ \\
\hline \multirow[t]{6}{*}{ 'Autumn Brilliance' } & Genesee & 6 & $5.1^{x}$ & $4.0^{x}$ & $3.9^{x}$ & $3.9^{x}$ & 4.9 & $8.0^{\mathrm{w}}$ \\
\hline & Warren & 6 & 5.1 & 4.4 & 3.1 & 4.8 & 4.8 & 7.3 \\
\hline & Reading & 6 & 6.4 & 4.2 & 2.5 & 3.2 & 3.4 & 5.0 \\
\hline & Union City & 6 & 6.4 & $4.2^{x}$ & $3.4^{x}$ & $3.1^{\mathrm{x}}$ & 4.4 & 6.0 \\
\hline & Meadville & 3 & 4.6 & 4.2 & $2.8^{\mathrm{x}}$ & 4.4 & 3.8 & 7.6 \\
\hline & Blairsville & 3 & 5.6 & 3.9 & $1.8^{x}$ & 4.7 & 4.9 & 8.5 \\
\hline \multirow[t]{8}{*}{ 'Cumulus' } & Orrstown & 6 & 4.6 & 3.4 & 2.4 & 4.4 & 4.6 & 7.5 \\
\hline & Genesee & 6 & $7.1^{x}$ & $5.4^{x}$ & $2.9^{x}$ & $3.4^{x}$ & 4.9 & $7.0^{\mathrm{w}}$ \\
\hline & Waverly NY & 7 & 5.3 & 4.2 & - & 4.0 & 4.3 & 6.4 \\
\hline & Del. Water Gap & 6 & 4.8 & 4.4 & 2.7 & 2.9 & 4.4 & 5.8 \\
\hline & Bedford & 8 & 9.1 & $6.4^{x}$ & $3.0^{x}$ & 3.6 & 4.6 & 6.2 \\
\hline & Reading & 6 & 9.1 & 5.5 & 3.2 & 2.4 & 3.3 & 4.5 \\
\hline & Blairsville & 3 & 5.6 & 4.1 & $1.3^{x}$ & 4.5 & 4.9 & 8.4 \\
\hline & Williamsport & 3 & 5.6 & 4.8 & $1.7^{\mathrm{x}}$ & 4.4 & 5.0 & 7.6 \\
\hline 'Princess Diana' & Meadville & 3 & 4.6 & 3.7 & $2.4^{x}$ & 4.4 & 4.2 & 7.9 \\
\hline \multirow[t]{6}{*}{ 'Robin Hill' } & Orrstown & 6 & 5.6 & 4.0 & 2.5 & 4.4 & 4.6 & 7.3 \\
\hline & Waverly NY & 6 & 5.8 & 4.1 & - & 4.0 & 4.2 & 6.4 \\
\hline & Del. Water Gap & 6 & 5.6 & 4.6 & 2.9 & 2.8 & 4.7 & 6.6 \\
\hline & Bedford & 8 & 9.1 & $5.5^{\mathrm{x}}$ & $3.4^{x}$ & 3.5 & 4.4 & 5.3 \\
\hline & Reading & 6 & 8.6 & 5.3 & 2.8 & 2.1 & 3.1 & 5.3 \\
\hline & Williamsport & 3 & 5.3 & 4.5 & $1.4^{x}$ & 3.9 & 4.1 & 7.5 \\
\hline \multirow[t]{4}{*}{ Tradition ${ }^{\circledR}$} & Waverly NY & 7 & 6.6 & 4.4 & - & 4.0 & 4.3 & 6.9 \\
\hline & Warren & 6 & 5.1 & 4.5 & 2.9 & 4.7 & 4.8 & 7.1 \\
\hline & Reading & 6 & 5.8 & 3.5 & 2.3 & 3.4 & 3.6 & 5.1 \\
\hline & Union City & 6 & 6.1 & $5.0^{x}$ & $2.9^{x}$ & $2.6^{x}$ & 4.4 & 5.4 \\
\hline
\end{tabular}

${ }^{2}$ Foliage and branch injury ratings: $1=65 \%$ to $100 \%, 2=45 \%$ to $60 \%, 3=25 \%$ to $40 \%, 4=5 \%$ to $20 \%, 5=1$ ess than $5 \%$. YOverall ratings: $0=$ unsuitable to $9=$ ideal.

${ }^{x}$ Cultivars at the same location differ significantly at the $95 \%$ level.

${ }^{\text {w }}$ Cultivars at the same location differ in overall rating by at least 1.0 .

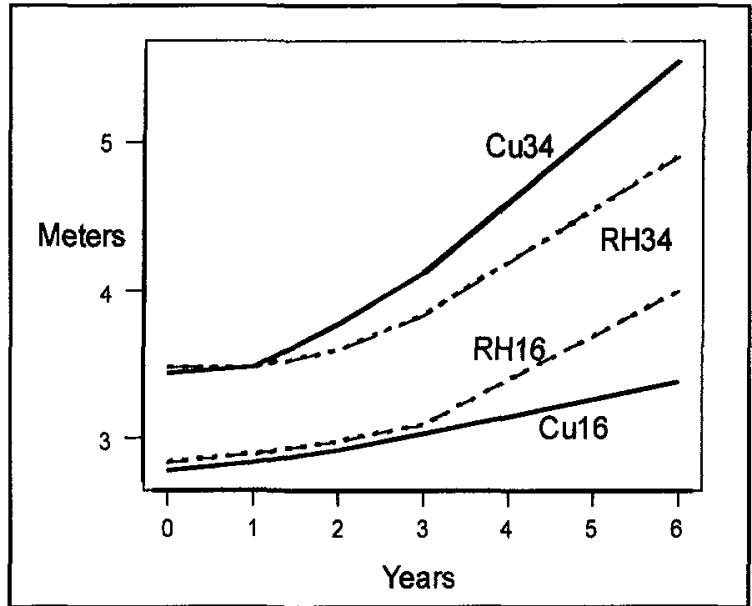

Figure 1. Height growth of 'Cumulus' $(\mathrm{Cu})$ and 'Robin Hill' (RH) serviceberry cultivars at Orrstown (Test 16) and Bedford (Test 34).

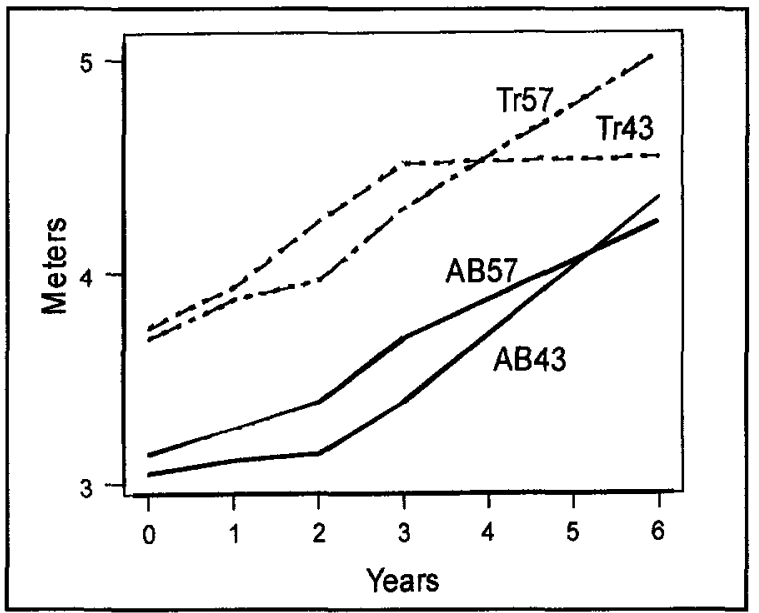

Figure 2. Height growth of 'Autumn Brilliance' $(\mathrm{AB})$ and Tradition ${ }^{\circledR}$ (Tr) serviceberry cultivars at Warren (Test 43) and Union City (Test 57). 
Acknowledgements. Financial support for the Municipal Tree Restoration Program was provided by utility companies through the Pennsylvania Electric Energy Research Council and by donations from arboricultural firms: ACRT, Allegheny Power Systems, Asplundh Tree Expert Co., Bartlett Tree Expert Co., Duquesne Light, Environmental Consultants Inc., GPU Energy and Genco, Hazlett Tree Service, Penn Power, Pennsylvania Power \& Light, and UGI Corporation. Service Foresters of the Pennsylvania Bureau of Forestry and the N.Y. Department of Environmental Conservation, and Extension Urban Foresters of Penn State University, assisted with community liaison and tree measurements.

\section{Professor of Forest Genetics \\ School of Forest Resources \\ Penn State University \\ 109 Ferguson Building \\ University Park, PA 16802}

Résumé. Cinq cultivars d'amélanchier, deux de chacun dans 11 communautés, ont été plantés pour être évalués comme arbres de rues. Ils ont été mesurés annuellement durant trois ans, et périodiquement par après, par des collaborateurs du Programme municipal d'arbres de restauration au moyen de méthodes standardisées. Les cultivars Autumn Brillance, Cumulus, Princess Diana, Robin Hill et Tradition ${ }^{\circledR}$ ont tous bien fonctionné dans certaines localités. Mais ils ont souffert quelque peu des stress urbains. Autumn Brillance avait le feuillage le plus en santé, le plus haut taux de survie et était le plus large mais pas aussi haut que les autres.

Zusammenfassung. Fünf Speierling-Arten, jeweils zwei aus elf Gemeinden, wurden gepflanzt, um ihre Tauglichkeit als Strassenbäume zu bewerten. Sie wurden jährlich über einen Zeitraum von drei Jahren und auch noch in periodischen Abständen hinterher durch Mitarbeiter des kommunalen Baumpflanzprogramms mit standartisierten Methoden gemessen. Autumn Brillance, Cumulus, Princess Diana, Robin Hill und Tradition ${ }^{\circledR}$ entwickelten sich an einigen Standorten sehr gut. Aber sie litten etwas unter den Stadtbedingungen. Autumn Brilliance hatte ein gesünderes Laub, höhere Überlebensraten und war breiter, aber nicht größer als die anderen.

Resumen. Cinco cultivares del árbol de bayas (service tree), dos de cada uno en once comunidades, fueron plantados para su evaluación como árboles urbanos. Se midieron anualmente durante tres años, y después periódicamente, en cooperación con el Programa de Restauración de Arboles Municipales usando métodos estándar. 'Autumn Brillance', 'Cumulus', 'PrincesS Diana', 'Robin Hill', y 'Tradition' (B) funcionaron bien en algunas localidades. Pero sufrieron algo de estrés urbano. 'Autumn Brillance' tuvo el follaje más saludable, mayor supervivencia y más anchura, aunque no tanta altura como los demás. 